\title{
Recovering lost lives: researching women in legal history
}

Article

Accepted Version

Auchmuty, R. (2015) Recovering lost lives: researching women in legal history. Journal of Law and Society, 42 (1). pp. 34-52. ISSN 0263-323X doi: https://doi.org/10.1111/j.14676478.2015.00697.x Available at https://centaur.reading.ac.uk/39419/

It is advisable to refer to the publisher's version if you intend to cite from the work. See Guidance on citing.

To link to this article DOI: http://dx.doi.org/10.1111/j.1467-6478.2015.00697.x

Publisher: Wiley-Blackwell

All outputs in CentAUR are protected by Intellectual Property Rights law, including copyright law. Copyright and IPR is retained by the creators or other copyright holders. Terms and conditions for use of this material are defined in the End User Agreement.

\section{www.reading.ac.uk/centaur}

\section{CentAUR}

Central Archive at the University of Reading

Reading's research outputs online 


\title{
RECOVERING LOST LIVES: RESEARCHING WOMEN IN LEGAL HISTORY
}

\section{Rosemary Auchmuty}

\begin{abstract}
Drawing on the research I undertook into the life of Gwyneth Bebb, who in 1913 challenged the Law Society of England and Wales for their refusal to admit women to the solicitors' profession, this article focuses on the range of sources one might use to explore the lives of women in law, about whom there might be a few public records but little else, and on the ways in which sources, even official ones, might be imaginatively used. It traces the research process from the case that inspired the research Bebb $v$ The Law Society [1914] 1 Ch 286) through to the creation of an entry in the Oxford Dictionary of National Biography and what this means for women's history, emphasising the importance of asking the 'woman question' and seeking out the broader significance of a woman's life in the context of her times.
\end{abstract}

There are very few biographies of legal women in the UK. This is partly because very few such women have been considered important enough to merit the conventional type of study, based on their contribution to public life, but also because women's legal history has also not, until recently, been considered important enough for academic study. Paradoxically, what this really meant was that it was too important, for to reveal women's legal history too clearly would be to uncover the many mechanisms by which men have retained power for themselves in law and to give the lie to the vaunted equality of opportunity for men and women. Today, fortunately, no scholar need apologise for focusing on women; the problem is, rather, the paucity of information about those legal pioneers, for whom records have not been kept precisely because their lives were deemed unimportant. This means we have to be imaginative in our search not only for source material but actually for women subjects to research, and to ask different questions of the public records that do survive and have been written up in the past.

As Karen Tani puts it, the task of historical scholarship is

to continually assess and re-assess significance; to take existing categories and orderings and reconstruct them, so that raw data, new and old, becomes meaningful to today's consumers. It is especially the task of historians of women, since their data is so often cast into the 'unimportant' bin. ${ }^{1}$

Painstaking research by Patrick Polden, ${ }^{2}$ Anne Logan, ${ }^{3}$ Hector MacQueen ${ }^{4}$ and others has uncovered the names of many of the 'firsts' among English and Scottish legal women

\footnotetext{
${ }^{1}$ K.M. Tani, 'Portia's Deal' (2012) 87 Chicago-Kent Law Review 569

${ }^{2}$ P. Polden, 'Portia's Progress: Women and the Bar, 1919-1939' (2005) 12 International Journal of the Legal Profession 293-338

${ }^{3}$ A.F. Logan 'In Search of Equal Citizenship: the campaign for women magistrates in England and Wales, 1910-1939’16 'Women's History Review (2007) 501-518
} 
but, as they found, naming them is just the start; in trying to reconstruct what it was like to be one of these pioneers, and to fill in the context of their lives, not simply the public struggles and achievements but also, if possible, the private ones - the source problem is magnified a hundredfold, for personal records are so rarely kept. Even sizable archives like that of Helena Normanton (early woman barrister and contemporary of Miss Bebb) contain no personal papers. ${ }^{5}$ Mary Jane Mossman's The First Women Lawyers ${ }^{6}$, which compares the experiences of early women lawyers in the United States, Canada, England, New Zealand, India and some continental jurisdictions, benefited from a reasonably wide range of public sources, while for her North American case studies she was assisted by an increasing body of doctoral dissertations on early women lawyers. Nevertheless the amount of effort in recovering these stories was prodigious and she had to ask different questions from the usual 'tale of progress' to reach the uncomfortable conclusion that admission to the legal profession was the start, rather than the end, of women's struggle for quality.

For what I actually found out about Miss Bebb, I refer readers to the substantive article in Legal Studies. ${ }^{7}$ In brief, she studied law at Oxford, worked for some years in government service, brought the test case against the Law Society, married and had a child, all the while playing an active role in a well-organised, persistent and very public campaign (about which the institutional histories are totally silent) for the admission of women to the legal profession, eventually won in 1919. But she died before she could be called to the $\operatorname{Bar}^{8}$ and this accounted for her disappearance from history.

The present article focuses on the method and process of undertaking a biography of this type when the sources are elusive or absent, as is so often the case with women. It begins with a consideration of case law as a historical source, since my own research started thus. While legal scholars are uniquely qualified to understand the legal reasoning behind a judgment (something often misunderstood or ignored by non-legallytrained historians), they are apt to forget that judgments are products of their time, as susceptible of historical analysis as any other primary source (Who is speaking? For what

\footnotetext{
${ }^{4}$ H. MacQueen 'Scotland's first women law graduates: an Edinburgh centenary' in Miscellany VI (Edinburgh, Stair Society, 2009) 221-265

${ }^{5} \mathrm{~J}$. Bourne, Helena Normanton and the Opening of the Bar to Women. Unpublished PhD thesis, University of London, 2014

${ }^{6}$ M. J. Mossman, The First Women Lawyers: A Comparative Study of Gender, Law and the Legal Professions (Oxford, Hart Publishing, 2006)

${ }^{7}$ R. Auchmuty, 'Whatever happened to Miss Bebb? Bebb v The Law Society and women's legal history' (2010) 31 Legal Studies 199-230

${ }^{8}$ As Patrick Polden established (above n 2), but he did not investigate the cause of death, which formed the basis of my own interpretation of her life
} 
purpose? Who is the audience? What is the context?). The article then considers how the biographer might move from the case to other, sometimes unexpected, sources, and how these sources can - indeed, must - be creatively used in order to elicit information not always apparent on their face, or able to be extrapolated or conjectured across to one's subject. It concludes with an assessment of the significance of this kind of biographical study, which extends above and beyond the telling of an individual life.

\section{Starting from the case}

My research was inspired by a case: Bebb v the Law Society [1914] 1 Ch 286. It is sometimes mentioned in history books but with little detail or context. The Court of Appeal decision is easy enough to find; it was reported in both the Law Reports and the Times Law Reports. Characteristically for the time, the reports are is quite short, though Counsels' main arguments are included and all three justices pronounced. The summary of facts tells us nothing about the plaintiff except that she was a 'spinster', a description repeated faithfully by my students, with all its misleading connotations - Miss Bebb was 23 years old at the time - and, less forgivably, by Manchester in his Modern Legal History. ${ }^{9}$ The Master of the Rolls mentions in his judgment that Miss Bebb was 'a distinguished Oxford student' (a clue to the biographer) ' - and at least equal to a great many, and probably, far better than many, of the candidates who will come up for examination, ${ }^{10}$ but,' he adds, 'that is really not for us to consider. Our duty is to consider and, so far as we can, to ascertain what the law is, and I disclaim absolutely any right to legislate in a matter of this kind'. ${ }^{11}$ In that disclaimer, of course, lies the reasoning behind the outcome. His fellow-judges agreed: 'We are not here to say what should be the law,' Phillimore LJ states. '.. Our function is to declare the law'. ${ }^{12}$ Neither he nor SwinfenEady LJ says anything about Miss Bebb.

The era before the first world war is widely-regarded as a conservative one for judicial law-making. ${ }^{13}$ J.A.G. Griffith, however, argued forcefully that judges in all periods have demonstrated judicial creativity when they wanted to and, further, that the notion of judicial neutrality is a myth. ${ }^{14}$ Certainly the spirited arguments of Miss Bebb's Counsel, Lord Robert Cecil KC, suggest that a different outcome was not inconceivable. He drew on precedents of women in public life, persuasive practice in other common-

\footnotetext{
${ }^{9}$ A. H. Manchester, A Modern Legal History of England and Wales 1750-1950 (London, Butterworths, 1980) 70

${ }^{10}$ As I subsequently discovered, she had a first from Oxford.

${ }^{11}$ Bebb v the Law Society [1914] 1 Ch 286 at 294

${ }^{12}$ Ibid at 297

${ }^{13}$ See, e.g., R. Stevens, Law and Politics: The House of Lords as a Judicial Body 1800-1976 (North Carolina, University of North Carolina Press, 1978).

${ }^{14}$ J.A.G. Griffith, The Politics of the Judiciary (London, Fontana, $5^{\text {th }}$ ed. 2010) Part 3.
} 
law jurisdictions, and the wording of the statute under consideration - section 2 of the Solicitors Act 1843, which mentioned 'persons', and section 48, which said that words importing the masculine gender were to be taken as applying also to women. In her comparative study, Mary Jane Mossman notes that the same precedents were used by judges in other common-law jurisdictions to justify opening the profession to women. ${ }^{15}$ The fact that a woman was willing to challenge the law in England, and the fact that leave to appeal was granted, indicate that there was some will for change. People do not present themselves as test cases out of the blue. They nearly always represent a wider constituency, one that enjoys a measure of support and probably organisation. In 1912, first-wave feminism was at its zenith, with a strong and active suffrage movement and votes for women seemingly just around the corner. I was keen to discover more about Miss Bebb and her associates and how she fitted into all this.

\section{Biography in judgments}

I am not the first person (it goes without saying) to want to find out more about the story behind a case. Brian Simpson famously explained how, confronted by the very first case he read as a law student ( $R v$ Dudley and Stephens [1884] 14 QBD 273), his curiosity about the context stood in the way of his comprehension of the legal principle. Questions piled up in his mind:

Who were these men? What on earth were they doing in the South Atlantic in a yacht? Why did it founder? Why did they not keep quiet about the whole affair, given the fact that the principal evidence against them had been consumed? Why just six months' imprisonment? What became of them afterwards? Only, it seemed to me, by answering these questions could this weird case be undertood (my emphasis). ${ }^{16}$

He noted, however, that this reaction - almost instinctive for a legal historian - was at odds with the prevailing legal pedagogy. Richard Ireland confirms:

As lawyers, we often lose the people behind the law, the circumstances and personalities in the intensely personal dramas which eventually lead to the headnotes of our authorities. The more personal and contextual details, as Simpson reminds us, we are taught to consider as legally irrelevant. ${ }^{17}$

Law teachers who practise a socio-legal approach are torn. On the one hand, we try to wean our students away from the superfluous re-telling of facts every time they apply an authority to a problem. On the other, we want them to be able to situate case law in its social and political context, if only to show how cases may be distinguished and the law

\footnotetext{
${ }^{15}$ Mossman, above n 6, 278

${ }^{16}$ A.W. B. Simpson, Leading Cases in the Common Law (Oxford, Clarendon Press, 1995) 9

${ }^{17}$ R.W. Ireland, 'Sanctity, superstition and the death of Sarah Jacob' in A. Musson and C. Stebbings (eds) Making Legal History: Approaches and Methodologies (Cambridge, Cambridge University Press, 2012) 300
} 
developed. What matters, of course, is which facts are emphasised, and what is done with them. ${ }^{18}$ A further problem is that many of the facts a biographer or historian might be interested in are not, in fact, those highlighted (or even mentioned) in the case report. ${ }^{19}$

The suppression of superfluous or 'irrelevant' facts in the study of case law arises from the attempt, which began towards the end of the nineteenth century with the production of the first law textbooks, to impose a form of scientific logic on the development of the common law. Legal reasoning became a process of finding (and, in some cases, writing back into past decisions) an evolving legal principle, while paring down the facts of cases to the bare distinguishable (or not) elements. It is easy to see why this happened: more and more cases were being decided, law reports were correspondingly more voluminous and comprehensive, legal education was expanding and legal academics were trying to establish law as a subject for university study rather than simply a practical apprenticeship. The whole tenor of Victorian life was, in any case, conducive to the scientific approach. There is no denying that the appearance of textbooks greatly facilitated students' learning of law but the effect was to over-simplify, confuse and, at times, obliterate the historical context which had contributed to legal decisions and developments. When we look at some of the textbooks on the market today we can see this process of reducing law to an exact science raised to the highest and most regrettable level.

That said, the omission of 'irrelevant' facts was not simply a textbook technique, it was also characteristic of the judgments of the time. The Court of Appeal judgments in Bebb illustrate this tendency. While facts have played a greater or lesser role in legal decision-making at different periods and at the hands of different judges, it is clear that the more scientific the court's approach (that is, the more the judge simply applies the 'relevant' principle), the fewer facts will be revealed and the less we will be told about the particular circumstances of the litigants.

There are two reasons for this. First, giving details of the claimants' lives and situation is likely to engender empathy, if not sympathy, making an unfavourable verdict harder to deliver and justify. No wonder then that judges might avoid the uncomfortable detail. Second, information of this sort often serves to highlight the gap

\footnotetext{
${ }^{18}$ For a discussion of the importance of fact-telling for feminists, see R. Hunter, 'An account of feminist judging' in R. Hunter, C. McGlynn and E. Rackley (eds) Feminist Judgments: From theory to practice (Oxford, Hart Publishing, 2010) 36 and, for the application of these principles, see the judgments contained in this volume, passim.

${ }^{19}$ It is also true that the court and/or the report might get the facts wrong. See R. Auchmuty, 'The Fiction of Equity' in S. Scott-Hunt and H. Lim (eds) Feminist Perspectives on Equity and Trusts (London, Cavendish. 2001); D Watkins 'Recovering the lost human stories of law: Finding Mrs Burns' (2013) 7 Law and Humanities 68
} 
between the assumptions behind the principle relied upon and the reality on the ground, and thus to raise doubts as to the suitability or justice of the principle itself. In Miss Bebb's case, for instance, the principle which caused her challenge to fail was the one that said that women had always been barred from public office. Yet Miss Bebb in the very year the case was heard, in 1913, was working (as I subsequently discovered) as an Investigating Officer for the Board of Trade, in which role she brought prosecutions against employers in the sweated trades. In other words, she was employed in the public sector doing exactly what a qualified solicitor would do. This went unmentioned in the judgment, lest the outcome be too clearly revealed as senseless and contradictory.

By way of comparison, let us briefly consider the use made of biography and context by that master of legal narrative, Lord Denning. Denning was a great judge partly because his knowledge of the law was so extensive he could conjure up a precedent for every result he wished to reach, but partly for his ability - and willingness - to advance the law in situations where he believed this would procure justice. His technique of starting his judgments by situating the parties and their actions in the context of their place and time marked a break from the earlier practice of ignoring biography and context, and it enabled Denning to do precisely what the judges in Bebb could not and would not do: to develop the law by (a) engaging sympathy for the unjustly-treated claimant (Denning by his own account single-handedly revived the equitable jurisdiction $)^{20}$ and (b) exposing the contradiction between a legal principle based on a particular conception of society and the reality of people's social circumstances at that moment in time. This helps to explain why Denning contributed so significantly to the development of rights for women in the 1960s and 1970s, because women's situation changed so profoundly across the twentieth century, beginning with the advances of the first-wave feminist movement of which Miss Bebb was part, and continuing with those of second-wave feminism which precipitated so many women into the courts during Denning's time as Master of the Rolls.

Here is one example, offered simply to show how, in different times and with different judges, Miss Bebb's case could have been decided differently. In Williams $\delta$ Glyn's Bank v Boland (1978) 36 P \& CR 448 (Ch D), Templeman J found the idea that Mrs Boland might have an overriding interest against the bank impossible in law and impracticable in practice (it would have 'almost catastrophic effects,' he warned). ${ }^{21}$ Lord

\footnotetext{
${ }^{20}$ Lord Denning wrote many wonderfully expressive accounts of his life and role in law-making. See, inter alia, 'The rights of women' in The Changing Law (London, Stevens, 1953) 79-98; The Due Process of Law (London, Butterworths, 1980); and The Family Story (London, Butterworths, 1981).

${ }^{21}$ Williams \& Glyn's Bank v Boland (1978) 36 P \& CR 448, at 454
} 
Denning in the Court of Appeal, however, deftly disposed of these objections by exposing, while never actually saying so, the fact that Templeman's real objection was to the idea that women might have separate interests in the home from their legal-owner husband's. Such a notion was inconceivable to judges comfortable with the traditional image of breadwinner husband and dependent wife that had dominated British society up to the 1950 s.

Noting the finding by both Stamp J in Caunce $v$ Caunce ${ }^{22}$ and Templeman $\mathrm{J}$ in Boland that lenders cannot be said to have notice of occupying wives, Denning says:

I profoundly disagree. Such statements would have been true a hundred years ago when the law regarded husband and wife as one; and the husband as that one. But they are not true today. ${ }^{23}$

And of course they were not. Mrs Boland, as Denning explained at the outset, was a nurse, married for 20 years to a builder. Both husband and wife worked (they had only one child) and both had contributed to the purchase of the home in dispute, as well as to a previous one. Denning sets out these facts at the very start (Templeman tells us absolutely nothing about Mrs Boland except that she is Mr Boland's wife) so that later he can reach a radical new understanding of the law by demonstrating that the denial of rights to women in her situation is contrived, out of step with modern circumstances (not to speak of common sense) and, indeed, unfair.

Let us now consider one more aspect of Denning's judgment technique, which demonstrates more than that of any other judge except, perhaps, Lady Hale, how biography and context can work for women litigants. Just as he generalises from the individual litigant to women as a group, so Denning sometimes uses the reverse technique, starting from the general and ascribing this to the particular. While this is obviously very effective as a rhetorical device, it also enabled him to fill in gaps in the facts - the very technique I was to use when trying to fill in the gaps in Miss Bebb's life. Templeman J, for example, observed in the lower court that Mrs Boland could have protected herself by entering a spouse's right of occupation (referred to as a Class $\mathrm{F}$ charge) on the Land Register. Lord Denning, not knowing precisely why Mrs Boland had not done so (but a clue may lie in the fact that this right only became available to wives

\footnotetext{
22 [1969] WLR 286

${ }^{23}$ Williams \& Glyn's Bank $v$ Boland above $\mathrm{n} 10$, at 560. This reference to the doctrine of coverture, largely abolished by the Married Women's Property Act 1882 (literally, almost a hundred years before), show all too clearly how old values die hard with those who benefit from them.
} 
with a beneficial interest in the property after the property in dispute had been purchased), ${ }^{24}$ instead generalised as to how women like her would have behaved:

But that amendment was of precious little use to her, at any rate when she was living at home in peace with her husband. She would never have heard of a Class F charge: and she would not have understood it if she had. ${ }^{25}$

This is patronising, perhaps, but effective and, what is more important, probably true and it is also, of course, the reason why overriding interests were introduced into the Land Registration Act 1925 in the first place: to protect those who would not think of registering their right. But the point I wish to make in this article is that sometimes, in trying to construct a life of someone for whom few records are available, the biographer may have to conjecture from the general to the particular.

\section{Getting behind the case}

Once you begin to ask intelligent questions about cases, questions directed to understanding the case as a historical event, it is fairly obvious that you have to seek for answers in sources other than law reports ... ${ }^{26}$

I wanted to find out more about Miss Bebb - her family background, her Oxford experience, her role in the trial and her later life. So - where to start? The obvious place would be the Register of Births, Deaths and Marriages at St Catherine's House, and to follow up with visits to the archives of her Oxford college, the Law Society, and her Inn of Court. But the truth is that, these days, we tend to go first to the internet, and this is what I did. Websites provide a valuable forum for genealogists, local history societies, independent researchers and bloggers to publicise their work, in addition to leading us to published books, articles and archives. But they need to be treated with caution. The same ideas, the same stories get repeated endlessly and we can easily fall into the trap of seeing this as corroboration. Often it is not; it's the just the same, possibly mistaken, source being repeated again and again - as I found. The story of Miss Bebb's legal challenge to the Law Society has been re-told so often that I thought, writing my article, that I could skim over this bit - that a brief summary of what happened would do. In fact, although I called it 'a brief summary', the account ran to two pages because what was in the public domain seemed to me so misleading. This meant that, before I even

\footnotetext{
${ }^{24}$ The ability to register a spouse's right of occupation was introduced in the Matrimonial Homes Act 1967, but applied only to wives with no interest in the property. Section 38 of the Matrimonial Proceedings and Property Act 1970 extended the right to wives with a beneficial interest. The Bolands, however, had bought their house in 1969. Moreover, Mrs Boland thought the property had been registered in joint names, as their previous home had been. Nothing was said in the Report as to why she thought this. We can infer that, as in Caunce (above $n$ 11), neither the bank nor her husband had bothered to tell her.

${ }^{25}$ Williams \& Glyn's Bank $v$ Boland, above $\mathrm{n} 10$ at 556, my emphasis

${ }^{26}$ Simpson, above $\mathrm{n} 14,10$
} 
embarked on finding out about my subject's life beyond her legal action (my initial goal), I had to check the facts of the case itself and revise existing accounts of the campaign that led to it. Even the public records had been misrepresented, and that was before I even got to the private ones!

This brings us to the second consideration of the legal biographer, which is equally crucial. Without sources, you can't really say much that is authoritative about your subject; but, even with them, you won't produce anything worthwhile unless you ask the right questions of your sources. Many short biographical studies - articles, say, like the one I was writing - present the known facts of the subject's life but fail to consider the questions that might immediately occur to the reader. Questions like, What was it like to be in that situation? How would that event have affected that person? In the absence of any direct reference, many scholars are loathe to 'speculate' (as they see it); and critics can be scathing about assertions like 'she must have ...' or 'she would have ...' (a criticism which incidentally never bothered Lord Denning).

So we have two problems: our 'facts' are not always true, as published accounts may be wrong, and our conjectures may not be founded in 'fact' - so we end up with maybe two sentences: birth, death, and a few achievements in between that can be conclusively 'proved' to have happened.

How biographers deal with these two considerations depends fundamentally on what their aims are in tackling this particular life. It is why one account can differ so greatly from another; it is why history is often described as a 'dialogue between the past and the present'; and it is why we train research students to come up with a research question. What do you want to find out? What is the issue for you? It isn't 'all I know about $\mathrm{X}^{\prime}$ for a biography any more than it is for an answer to an exam or coursework question.

In my case, the research question was the title of my article: 'Whatever happened to Miss Bebb?' If you read any history of the English legal professions, she will probably rate a mention - or her case will - but that will be it. One mention; then she's gone. Now women get little enough attention in institutional histories, but Helena Normanton, Ivy Williams, other feminist pioneers - we can construct lives for them from other available sources. ${ }^{27}$ Miss Bebb, however, was just a case name. I didn't even know her first name when I started; she didn't appear in the Oxford Dictionary of National Biography or Who's Who. But even once I discovered this, and something about her background and

\footnotetext{
${ }^{27}$ Both have entries, with attached references, in the Oxford Dictionary of National Biography, www.oxforddnb.com
} 
education, I still could not understand why more was not heard of her subsequently. So I set myself the task of finding out.

\section{Asking questions that matter}

I do think that telling the story of any human being's life is worth doing, especially a woman's, since women have been (as Sheila Rowbotham put it in her pioneering book more than 40 years ago) Hidden from History ${ }^{28}$ for so long. But a life on its own is not always interesting per se; sometimes I read an account and think (I am sorry to say), So what? Individual life accounts are useful source material for social historians who can aggregate experiences and make generalisations or offer them as examples, but they are not necessarily fascinating on their own.

After some research, I was able to establish why Miss Bebb disappeared from legal history. She married, so she changed her name; then she died before she had qualified as a lawyer, so she dropped out of the story altogether. So I answered my question.

But was this enough? No - the 'So what?' question remained. But by then I knew enough about her life to be able to make a bigger argument about women's place in history generally. Once I found out that she had died in childbirth, I recognised that, unlike most other pioneer professional women who had been able to pursue their careers largely because they did not marry (like Ivy Williams) or did not have children (like Helena Normanton), the fact that Miss Bebb had wanted both a career and a family was actually her undoing. The penalty she paid for this choice, which men did not have to make, was not simply a professional but a biological one. She died because women, unlike men, bear babies, and because maternal health care was not a high priority in early twentieth-century Britain. Mothers suffered, mothers died; maternal maternity, though sad, was routine. In this sense, then, Miss Bebb stood for a much larger group of women, because what happened to her happened because she was a woman. Indeed, everything in her life was different because she was a woman. Different from what? From the normal human story - the usual history of the professions or public life: the story of the male experience, a world in which women were excluded or treated differently, and into which we were eventually subsumed, as if nothing had happened.

So one of the questions any historian or biographer must ask (whether researching a male or female figure) is the woman question. You must ask, does this statement, law or situation apply to both sexes or only to men? If to both, how would

\footnotetext{
${ }^{28}$ S. Rowbotham, Hidden from History: 300 Years of Women's Oppression and the Fight Against It (London, Pluto Press, 1973)
} 
their experiences of the same phenomenon be different? If only to men, where are the women? What was happening to them?

Miss Bebb, for example, was among the second generation of women who were admitted to Oxford. In theory, she could have had the same education as men; she certainly had the same teachers and sat the same exams. But of course her experience of Oxford was totally different from the men's. She lived in a small, poor women's college (which was nevertheless an intensely stimulating environment for a girl at the time). She got her first, but could not be awarded a degree. She studied law, but could not become a lawyer. We are fortunate that the editorial policy of the multi-volume History of the University of Oxford has been to include women at every point; this is one secondary source that responded to feminist critics, and I found it invaluable for details of degree courses, personnel and university and college practices. ${ }^{29}$ But the sweep is so broad that one cannot rely on it for specifics - in particular, what was it like for Miss Bebb? She wrote no accounts of her life: no diaries, no memoirs. Where can we look for source material for women's 'different' experience, where none appear to exist?

\section{Exploring the range of sources}

I became interested in Miss Bebb as a consequence of research I did on early women law students at Cambridge and Oxford. ${ }^{30}$ In the course of that research I discovered that there had originally been four prospective litigants against the Law Society, all Oxbridge law students or ex-students, and Miss Bebb was chosen (for reasons we can only conjecture at) to bring the test case. I followed up all four but, where the other three women's careers could be established with relative ease, Miss Bebb's life - apart from that brief appearance - eluded record. This piqued my interest.

The former Women's Library in London, now re-located to the London School of Economics, holds the scrapbooks of two of her fellow-litigants, Nancy Nettlefold and Maud Ingram. ${ }^{31}$ A record not only of the celebrated case but of the entire campaign for women's entry into the profession, these collections of newspaper cuttings, invitations, programmes and transcripts are a wonderful resource, immediate and moving. Not all biographers will have access to such a scrapbook or to private papers containing such materials, but it must be stressed here that newspapers, both national and local (and

\footnotetext{
${ }^{29}$ See, for example, J. Howarth, “'In Oxford but ... not of Oxford”: the women's colleges' in M.G. Brock and M.C. Curthoys (eds) The History of the University of Oxford vol VII: Nineteenth-century Oxford Part 2 (Oxford, Clarendon Press, 2000) 248.

${ }^{30}$ R. Auchmuty, 'Early women law students at Cambridge and Oxford' (2008) 29 Journal of Legal History 63

${ }^{31}$ Later Mrs Crofts. She became a solicitor and wrote Women Under English Law (London, National Council of Women of Great Britain, 1925)
} 
sometimes trade journals too), are among the most useful and valuable sources available to us. Newspapers tell us what is news and Newspapers tell us what is news and, crucially, they tell us how it is presented to the public - with all the errors, misunderstandings and biases of which we must be conscious, as in all sources. They may offer rare photographic glimpses of your subject, while cartoons, editorial comments and letters to the editor provide critical viewpoints. We are fortunate in this electronic age that more and more newspapers are being indexed and made available online.

But the problem with the Women's Library scrapbooks was that they only took Miss Bebb's story up to 1920, when women were admitted to the legal profession. To find out about the rest of her life, I sought out the birth, death and marriage certificates of Miss Bebb and her daughters. These are the building blocks of biography and, in the case of the marriage and death certificates, were to provide the essential clues to Miss Bebb's fate. But taking such sources on their own, in the absence of amplifying diaries, letters or reminiscences, sets up a rather individualised narrative. Poor Miss Bebb, what bad luck, she died in childbirth. A personal tragedy.

Of course it wasn't just like that. She died because of a public failing: her medical care was poor. It was poor because there was no National Health Service then and, crucially, because maternal health was not a government priority. It was poor because, even though the condition she died from was known and doctors might have been able to save her, she chose to have her baby in a nursing home (as middle-class women did) rather than a public hospital. I found statistics in Jane Lewis's still unsurpassed account

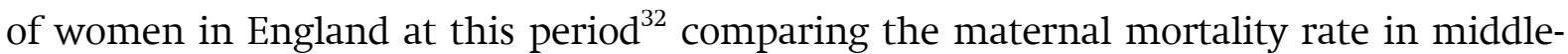
class Chelsea and working-class Hackney; the survival rate was better in Hackney, precisely because public hospitals were staffed by honorary consultants who knew what they were doing; and I used these to extrapolate that the risk for middle-class women in childbirth, unlikely as it might seem, was actually higher than for their working-class sisters at this time. Thus Miss Bebb is not just one unlucky individual but, in this situation, one of many people against whom the scales were weighted in terms of both gender and class.

I use this example to illustrate the technique I used for filling out the bare details of Miss Bebb's life. With no personal records to turn to, I fell back on context. This is where asking the right questions intersects with finding useful sources. Throughout my account, I kept asking myself: What would it have been like for her? You can never really get inside your subject, and I certainly never felt that Gwyneth Bebb and I had much in

${ }^{32}$ J. Lewis, Women in England 1870-1950 (Brighton, Wheatsheaf, 1984) 117-8 
common beyond our gender and our feminism. But I could still try to reconstruct her life in the context of the society in which she moved.

\section{Extrapolation and conjecture}

Many years ago I wrote a chapter in a book on lesbian history entitled 'By Their Friends We Shall Know Them'. ${ }^{33}$ Lesbian history was in its infancy then, a product of secondwave feminists' call for sexuality to be freely chosen (the seventh demand of the Women's Liberation Movement) and its insistence that sexuality was socially constructed, not inborn. Lesbian feminists recognised that patriarchal societies were sustained by what Adrienne Rich termed Compulsory Heterosexuality ${ }^{34}$ which included, alongside the categorisation of homosexuality as deviant and perverted, the suppression of all knowledge of same-sex relationships and non-heterosexual lifestyles in the past. My chapter was a study of women's friendship networks in Lambeth, where I lived at the time, intended to demonstrate that if you could identify some lesbians in history and then studied who they socialised with (these were all women in public life so there were plenty of sources for their lives), you could formulate a pretty good idea of which other women were lesbians at the time, in the absence of other evidence. If one woman lived with another, but had previously lived with a different woman who now lived with ... that sort of thing. I was not concerned to 'prove' anything, rather to suggest possibilities excluded in past accounts.

I used the same technique for Miss Bebb. If I couldn't find out anything first-hand about her, I would investigate her associates; and they might cast light on her own circumstances. I could extrapolate from what they said about the context in which she moved, to conjecture what her own experience might have been.

For her schooldays there was nothing; the school no longer exists. But an Oxford women's college at that time is a goldmine, because the colleges all have extensive archives. Not only that, but the women's colleges, like the men's, were populated by outstanding women, many of whom became prominent in public life and wrote memoirs or had biographies written about them. It was not difficult to find half a dozen accounts of life at the Oxbridge women's colleges in this period (there was also an institutional history of St Hugh's itself, which did not mention Miss Bebb) and I used these to try to reconstruct atmosphere, customs and rituals. For her law studies, which

\footnotetext{
${ }^{33}$ R. Auchmuty, 'By Their Friends We Shall Know Them: The lives and networks of some women in North Lambeth, 1880-1940' in Lesbian History Group (ed) Not a Passing Phase: Reclaiming Lesbians in History 1840-1984 (London, The Women's Press, 1989) 77

${ }^{34}$ A. Rich, 'Compulsory heterosexuality and lesbian existence' (1980) in Blood, Bread and Poetry: Selected Prose 1979-1985 (London, Virago) 23
} 
were shared with the men students, there were biographies of legal scholars to draw on (Holland, Dicey, Geldart, Vinogradoff and, especially, Holdsworth), as later there were biographies of the judges in the Bebb case and the leading politicians in Parliament (such as Lord Buckmaster and Lord Robert Cecil) who endorsed or opposed the various reforming Bills. The Oxford Dictionary of National Biography, with its helpful bibliographies, was a constant resource, for one entry led often to another. For instance, I discovered that Violet Markham, with whom Miss Bebb worked in the National Service for Women during the war, was a close friend of Jack Hills, ${ }^{35}$ the solicitor MP who introduced the 1913 Bill to open the solicitors' profession to women in the wake of the failed court case. Another connexion was Sybil Campbell, later to become the first woman professional magistrate,${ }^{36}$ who worked with Miss Bebb at both the Board of Trade and the Ministry of Food and became godmother to her daughter Diana.

I am sure that these connexions are not accidental. Nor was it accidental that Miss Bebb went to work after finishing at Oxford with Clara Collet at the Board of Trade. It was not just that her legal talents would have been useful for the work; I feel sure that Miss Bebb must have known Miss Collet, because Miss Collet had studied law herself (at University College) and was a friend of one of the first women law students at Cambridge, who had been at school with her. The feminist world was a small one; probably everyone knew, or knew of, everyone else. This is important because advances for women are so often presented as the result of individual effort or, worse, concessions from above with no feminist input whatsoever.

In attempting to reconstruct Miss Bebb's experiences as a student at an Oxford women's college I drew on another type of source often overlooked by historians: fiction. 'College novels' form a distinct literary sub-genre for both adults and young people, and those written for girls were at their most fashionable in the very years that Miss Bebb was at university. Elsewhere I have $\operatorname{argued}^{37}$ that, while of course one must treat fiction as critically as any other source, the fact that it is 'not true' does not mean it can't be of assistance to the historian in capturing aspects such as shared assumptions, customs and the atmosphere of the time and place. The background for girls' college novels was in any case always carefully researched by professional writers like L.T. Meade (the most

\footnotetext{
${ }^{35}$ Jack Hills's entry in the ODNB does not mention his support of women's entry into the legal profession. It focuses instead on his contribution to fly-fishing!

${ }^{36}$ P. Polden (1999) 'The lady of tower bridge: Sybil Campbell, England's first woman judge', (1999) 8 Women's History Review, 505-526

${ }^{37}$ R. Auchmuty, 'The Woman Law Student and the Girls' College Novel' (2007) 19 Canadian Journal of Women and the Law 37
} 
popular writers for girls of the period), or, in other cases, drawn from the writer's own experience of college life. ${ }^{38}$

Be imaginative, then; look around the subject; immerse yourself in the culture and society of your period. Legal scholarship is too prone to cut itself off from the historical roots of our contemporary situation by confining itself to formal, abstract, stylised, dehumanised even, conventional legal sources. As law and literature scholars have long argued, literature can shed light on law since both are products of the same society and both are sources for its history.

\section{Seeing the bigger picture}

Sir John Baker, doyen of English legal historians, has written: 'The historian, like the lawyer, has to find something above and beyond the sources - a story, a changing institution, or an evolving idea'. He goes on:

We must have stored in the backs of our minds numerous questions arising from our own reading of the secondary literature, from our knowledge of what went on in other periods and places, and above all from the sources themselves. As we uncover more evidence, and try to sift out what is useful, we are simultaneously relating it to our older questions and formulating new ones, until now and again we see enough light to propose some answers. We never produce final answers, but we help to take the general understanding forward. ${ }^{39}$

This is true too for the biographer. However difficult and time-consuming the process of uncovering sources to piece together a life (and there is no denying that non-historians frequently underestimate and undervalue the effort involved in simply doing this), the end result is of little use unless the life is ascribed a significance. That is not to say that only the great figures of public life deserve to be recorded for posterity, as used to be received wisdom; ordinary people, people in the private sphere, people whose lives never came to anything much (all of which might be said of Miss Bebb) may still tell us something over and above the details of their own existence. Indeed, with some public figures whose biographies have been told the significance lies not so much in how they carried out their public role as in how they got there in the first place. What did it take for $\mathrm{X}$ to reach the bench, or $\mathrm{Y}$ to become the first whatever it was? Sometimes the story is one, not of merit and personal achievement, but of political intrigue, family connexions, or choices based on compromise. This is, regrettably, particularly true of many who have risen to positions of judicial or legislative power in this country.

\footnotetext{
${ }^{38}$ See, for example, L.T. Meade, The Girls of Merton College (London, Hurst and Co: 1911); Mrs Sinclair Stevenson, Hilary: the Story of a College Girl (Oxford, Oxford University Press, [1920]).

${ }^{39} \mathrm{~J}$. Baker, 'Reflections on "doing” legal history', in Musson and Stebbings, above n 15, 16
} 
When she came to edit The Macmillan Dictionary of Women's Biography (1982), Jenny Uglow (distinguished biographer of women) noted how difficult it was to select candidates, given that public achievement was the usual criterion for inclusion in a volume of this sort, when women had been so excluded and marginalised from public life. Obviously, some women had made their mark, and they were the people of whom biographies had been written or whom one might find in a standard history or reference work. They had to go in, but others were chosen because, although often omitted from those very histories, they had advanced women's position, so often considered irrelevant in mainstream accounts. Uglow also decided to include two other categories of woman, those who embodied stereotypes (such as witches and film stars) and those who had become legends, for whatever reason. She recognised that in putting together this motley bunch she was not 'presenting a book which was representative of women's achievements' but 'compiling a book of deviants'. ${ }^{40}$

But even women in public life have private lives too, and those of us who seek to write more extended studies than the entries in a reference book do not have to focus on the one to the exclusion of the other. One of the things I appreciated about the recent biography of pioneer woman judge Rose Heilbron by her daughter was the space devoted to the subject's private life, particularly insightful when produced, as here, by a close family member. ${ }^{41}$ Indeed, when writing about professional women in an era when women were constructed as responsible for domestic matters, one cannot really ignore the effect of this ideology on, on the one hand, their personal strategies for negotiating the two portfolios and, on the other, the opposition they faced from traditionalists who would exclude them from the public sphere altogether. From Miss Bebb to Rose Heilbron to today's aspiring young women lawyers, the struggle is the same, and this makes women's legal biography very much a dialogue between past and present.

\section{Creating heroines}

Uglow described two motivations for researching women. The first, given women's exclusion or marginalisation from historical accounts, is the need purely for information ('who were the women involved, where did they qualify, what did they go on to do'). The second, quite different, was 'a request for heroines'. ${ }^{42}$ Women, she explained, did not always want to see themselves portrayed as 'passive victims'; heroines were especially important for young people, lest they grow up believing, as some of us were

\footnotetext{
${ }^{40}$ J.S. Uglow (ed) The Macmillan Dictionary of Women's Biography (London, Macmillan, 1982) viii

${ }^{41}$ H. Heilbron, Rose Heilbron: The Story of England's First Woman Judge (Oxford, Hart Publishing, 2012)

${ }^{42}$ Uglow, above $\mathrm{n} 31$, viii
} 
educated to believe, that only men had achieved - or could achieve - anything in public life.

Law, of course, is notorious for constructing women as passive victims (except where it wants to suggest they 'asked for it'), so we cannot be surprised when our students are affected by this bias. But the truth is that we have precious few legal heroines out there, and our students need to understand that this is largely because women have been victims - not always passive ones - of a system of patriarchal power massively stacked against us, not simply in terms of what we achieved (or not), but also in terms of how our achievements have been recorded (or not). ${ }^{43}$ When I write my historical work I always have my students in mind - students for whom, as I realised recently when writing about the 1970s, I may as well have lived in the Victorian age, so distant seem the events and concerns of my own youthful feminism. For them it is often just 'back then' when women were unequal, the unspoken assumption being that we are equal now - so if women fail to achieve in this day and age it must be due to lack of merit or ambition or, employing that fashionable liberal notion, choice. ${ }^{44}$

Making someone into a heroine for posterity's sake carries a burden of responsibility. In the course of one's research one may well find what one perceives as flaws, contradictions, wrong decisions or inappropriate behaviour - our subjects are human, after all, and we all make mistakes - and we cannot edit these out, even as we attempt to account for them. Biographers must not falsify the account to fit a preconceived model of hero status, not just because we are not arbiters of correct feminist behaviour, but because we are not competent to judge what might have been the best course of action in circumstances we can only imagine. We may not feel particularly close to our subject; as I have said, I did not particularly identify with Miss Bebb. It is perhaps more difficult to be impartial when we do. When Barbara Babcock, herself a feminist pioneer (first woman appointed to the regular faculty at Stanford Law School, first woman director of the Public Defender Service in Washington, DC), tackled her biography of the woman who inspired the public defender service, Clara Foltz, ${ }^{45}$ she had to steer a course at once sympathetic and critical through a tale of mistaken decisions and erratic changes of direction. The book's achievement is that we nevertheless end up feeling inspired by Foltz's resourcefulness, energy, optimism and humanity.

Cornelia Sorabji, the first woman law student at Oxford and distinguished AngloIndian barrister, presents her biographer with a similar range of contradictions: was she

\footnotetext{
${ }^{43}$ They should read D. Spender, Women of Ideas (and what men have done to them) (London, Ark, 1983).

${ }^{44}$ On 'choice', see A. Diduck, 'What is family law for?' (2011) 64 Current Legal Problems 287-314

${ }^{45}$ B. Babcock, Woman Lawyer: The Trials of Clara Foltz (Stanford, Stanford University Press, 2011)
} 
or was she not a feminist? Whose cause did she serve ${ }^{46}$ Sorabji chose not to align herself with the British women's movement or Indian nationalism, yet she worked all her life for women and strove to break down the barriers to women in the legal profession. Who knows what routes she would have taken had she not been faced with the need to fit in, to be accepted and unthreatening in a racist, misogynistic society, simply to be able to accomplish the work she had been trained to do? Sorabji's life incidentally raises other challenges for the biographer. There is no shortage of primary source material, as she wrote voluminously. But her fascinating autobiography India Calling $(1934)^{47}$ is, as scholars have discovered, fanciful and unreliable to the point of fictitious. ${ }^{48}$ Lawyers, while accustomed to weighing legal testimony, tend to abandon their critical sense outside the legal forum, taking for granted the idea that a published life is more or less 'true'. But truth is relative (this is the reverse point of my remarks about college fiction above), and there is a long tradition of fictionalised female autobiography encompassing, for example, writers as distinguished as Gertrude Stein ${ }^{49}$ and Ann Oakley. ${ }^{50}$ Again, we need to understand the motives for this, which may well lie (inter alia) in the hostile environments in which women are forced to operate.

\section{Countering the myth of continuous progress}

One of the most persistent myths I sought to attack in the Bebb article was the myth of continuous progress. It is true enough that things are generally better for women now than they were in Miss Bebb's time, but it has certainly not been a steady uphill climb nor, crucially, an inevitable one, and things are not perfect yet. Institutional histories, especially legal ones, tend to set down a record in which the time is right for reform, attitudes have changed, those in power are benevolent. What gets left out is the steady, decades-long campaigns conducted by feminists (that dreadful word), female and male. And what also gets left out is the steady, decades-long resistance of the ruling group of legal men, supported no doubt by many women, reluctant to share their power.

\footnotetext{
${ }^{46}$ S. Gooptu, Cornelia Sorabji. India's Pioneer Woman Lawyer: A Biographer (New Delhi, Oxford University Press, 2010)

${ }^{47}$ C. Lokugé (ed), India Calling: The Memories of Cornelia Sorabji, India's First Woman Barrister (New Delhi, Oxford University Press, 2001)

${ }^{48}$ A. Burton, 'The Purdahnashin in her Setting: Colonial Modernity and the Zenana in Cornelia Sorabji’s Memoirs’ (2000) 65 Feminist Review 145; Mossman, above n 6, chapter 5

${ }^{49} \mathrm{G}$. Stein, The Autobiography of Alice B. Toklas (Harmondsworth, Penguin, 1933)

${ }^{50}$ A. Oakley, Taking It Like a Woman (London, Jonathan Cape, 1984). On autobiography as fiction, see L. Stanley, The auto/biographical I: The theory and practice of feminist auto/biography (Manchester, Manchester University Press, 1992). For a legal example, see M. Weaitt, 'Imagining Ivy Williams', http://www.academia.edu/169684/Imagining Ivy Williams, accessed 26/02/14
} 
Consider how the entry of women into the legal profession, if mentioned at all, is dealt with in the standard texts. Here is Manchester in his standard text, Modern Legal History (1980):

After the First World War, and the dramatically changed role which women played during the course of that conflict, society began to take a radically different view of women's proper role in society. In 1919 the Law Society resolved that women might be admitted to the profession. ${ }^{51}$

If I had a penny for every time women's legal advances were ascribed to changed social attitudes I would be a rich woman today. Yes, I always want to say when confronted with such accounts, attitudes changed - but why? Because the men suddenly decided it would be a good idea to let women in? Or might it be because women fought a long, arduous battle to convince them? You would think that the achievement of the vote and entry into the legal profession would somehow be linked in people's minds to the 50 years of first-wave feminist campaigns for precisely these goals. You would imagine that the advances in gender equality that took place in the 1970s, 80s and 90s might be due, perhaps, to the second-wave feminist campaigns for equal pay, against discrimination at work, against domestic violence and so on. But no. Law is offered to students as a series of top-down reforms responding to, at best, individual challenges like that of Miss Bebb; at worst, those unmotivated shifts in public opinion.

Cutting each generation off from its history is the most effective means of disempowering them: believing that equality has been achieved, young women are destabilised when they encounter persistent discrimination; every battle has to be refought; every wheel re-invented. Here again what happened in Miss Bebb's lifetime has been replayed over different issues in my own. This is, then, the final question that biographers must ask of their sources: why did all this happen in the way it did? Who was responsible, and who stood in the way, and, again, why?

\section{Conclusion}

When the Dictionary of National Biography was being revised in the last years of the twentieth century, a welcome decision was made to include many more women and representatives of minority interests beyond the great white men of the nineteenthcentury volumes. When it became clear that the editors were interested not simply in those who had succeeded in public life, but also in those through whose efforts important social changes were progressed, I was emboldened to write and suggest that

${ }^{51}$ Manchester, above n.9, 71 
Miss Bebb might be suitable for inclusion. The editors accepted my suggestion and invited me to write the entry.

This was a woman whose contribution to the legal profession had been ignored or dismissed by the institutional histories because it was deemed unimportant and whose contribution to feminism had been overlooked and forgotten because her early death robbed her of the chance to be England's first woman barrister. This was a woman who left no records, not even a will; whose 'voice' is only preserved in the transcript of the Bebb trial in the Chancery Division and in extracts from speeches in newspaper accounts (all formal settings); and whose life had to be painstakingly reconstructed from a few public records, a great deal of extrapolation and some shameless conjecture. But, given that the ODNB is often scholars' first port of call if they want to find out about an individual, my account of Gwyneth Bebb's life has become an important resource for future researchers. More than that, I am proud to have created, in the sense I have described, a heroine, someone for future legal campaigners to find, admire, perhaps; even to emulate, in the face of women's continued struggles for justice and equality. 